\title{
Cereal lipids
}

By W. R. MORrison, Department of Food Science and Nutrition, University of Strathclyde, I31 Albion Street, Glasgow GI ISD

Cereal lipids are useful sources of essential fatty acids (Table 1 ), tocopherols and pro-vitamin $A$ carotenoids, and they have a high metabolizable energy value. A reappraisal of some aspects of the nutritional value of cereal lipids seems appropriate in the light of recent developments in the areas of plant breeding and methods for quantitative analysis of lipids.

\section{Composition and distribution}

Cereal lipids are complex (Morrison, 1977; Nechaev \& Sandler, 1975; Weber, 1973), but for nutritional purposes they can be regarded as consisting of glycerides containing six fatty acids, plus tocopherols, carotenoids and other unsaponifiable matter.

The principal fatty acids are $16: 0,16: 1(n-7), 18: 0,18: 1(n-9), 18: 2(n-6)$ and I $8: 3(n-3)$, and the two essential fatty acids usually comprise about half of the total (Table 1 ). Linoleate $(18: 2, n-6)$ is formed by oxidative desaturation of oleate $(18: 1, n-9)$, and there is often an inverse relationship between the percentages of these two acids when fatty acid composition is altered genetically or by changed growing conditions (de la Roche, Alexander \& Weber, 1971; Flora \& Wiley, 1972; Jellum, 1970; Poneleit \& Baumann, 1970; Thompson, Jellum \& Young, 1973). Increased quantities of linolenic acid $(18: 3, n-3)$ in the growing embryonic axis of germinating grain are found in cereals during vernalization and development of cold hardiness (de la Roche, Andrews, Pomeroy, Weinberger \& Kates, 1972; de la Roche, Pomeroy \& Andrews, I975; de Silva, Weinberger, Kates \& de la Roche, 1975; Farkas, Déri-Hadlacsky \& Adonisz, 1975; Redshaw \& Zalik, 1968).

Table I. Lipid and essential fatty acid (EFA) contents of cereals (Morrison, 1977)

\begin{tabular}{|c|c|c|c|}
\hline \multirow[b]{2}{*}{ Cereal } & \multirow[b]{2}{*}{$\begin{array}{c}\text { Total lipid, } \\
\text { (wt. \%) }\end{array}$} & \multicolumn{2}{|c|}{ EFA (\% of total fatty acid } \\
\hline & & $18: 2$ & $18: 3$ \\
\hline Barley & 3.5 & $56-59$ & $4-7$ \\
\hline $\begin{array}{l}\text { Maize } \\
\text { Millet }\end{array}$ & $\begin{array}{l}0.4-17.0 \\
2.8-8.0\end{array}$ & $\begin{array}{l}35-66 \\
38-66\end{array}$ & $\begin{array}{l}3 \\
2-10\end{array}$ \\
\hline Oats & $2 \cdot 8-11.6$ & $3^{I-48}$ & $<5$ \\
\hline Rice (brown) & $<3.9$ & $25-47$ & 4 \\
\hline Rye & $2 \cdot 0-3 \cdot 5$ & $46-57$ & $7-10$ \\
\hline Sorghum & $2 \cdot 1-5 \cdot 3$ & $4^{2}-5^{6}$ & $1-5$ \\
\hline Triticale & $3 \cdot 2-4 \cdot 6$ & $57-5^{8}$ & $3-4$ \\
\hline Wheat & $2 \cdot 1-3 \cdot 8$ & $55-60$ & $3-5$ \\
\hline
\end{tabular}


Cereal lipids are conveniently grouped into neutral or non-polar lipids, glycolipids and phospholipids. The non-polar lipids form the bulk of the lipids in most tissues, and consist of free fatty acids and simple glycerides (mostly triglycerides) which are saponifiable, plus wax esters, steryl esters, free sterols, tocopherols and carotenoids (Morrison, 1977) which are mostly unsaponifiable.

The major glycolipids are digalactosyl diglyceride and monogalactosyl diglyceride, and there are usually six or seven other minor glycolipids. There are more glycolipids than phospholipids in wheat endosperm non-starch lipids (i.e., all endosperm lipids other than those inside the starch granules), but in other tissues glycolipids are minor components.

In all tissues and organelles, except in starch granules, the major phospholipids are phosphatidyl choline, $N$-acyl phosphatidyl ethanolamine and $\mathrm{N}$-acyl lysophosphatidyl ethanolamine, and there are usually at least six minor phospholipids.

Cereal starches are unique in containing monoacyl lipids which are present as amylose-inclusion complexes throughout the granules (Acker \& Becker, 1971; Morrison, 1977). In wheat, barley, rye and oat starches the lipids are mostly lysophospholipids (80-90\% lysophosphatidyl choline), but in maize starch the major lipid is free fatty acid. Since lipid is associated with amylose, there is more lipid in high-amylose starches than in normal starches, and almost none in waxy (high-amylopectin) starch (Acker \& Becker, I97I; Tan, S. L. \& Morrison, W. R., unpublished results). There is $34-55 \%$ I $8: 2$ in the fatty acids of the starch lipids.

The carotenoids include small amounts of $\beta$-carotene. Other carotenoids such as $\beta$-zeacarotene, $\alpha$-carotene, $\gamma$-carotene and cryptoxanthin, which are present in some cereals (Morrison, 1977), have half of the $\beta$-carotene structure and approximately half of the pro-vitamin A activity of $\beta$-carotene (Bauernfeind, 1972). Most of the carotenoids are xanthophylls (oxygenated carotenoids) which have no pro-vitamin A activity.

Maize and sorghum are the best sources of pro-vitamin A carotenoids. The yellowness of the endosperm correlates well with pro-vitamin A activity in maize (Grogan \& Blessin, I968; Mihajlović, Hadži-Tasković, Sukalović \& Marković, I971; Quackenbush, Firch, Brunson \& House, 1963), but not in sorghum (SiklosiRajki \& Faragó, 1974).

The composition of the tocopherols is different in each cereal (Table 2), and barley is the only cereal in which all eight naturally-occurring tocopherols have been reported (Morrison, 1977; Slover, 1971). The distribution of the tocopherols also varies within the wheat and maize kernels (Table 3 ).

Bieri \& Evarts (1975) found that corn oil, with a ratio of $\alpha$-tocopherol equivalent (mg $\alpha-\mathrm{T}+\gamma-\mathrm{T} \times 0 . \mathrm{I})$ : polyunsaturated fatty acid $(\mathrm{g})$ of 0.6 , contained at least twice the vitamin $E$ requirement for rats.

Beringer \& Dompert ( I976) used the expression I $49(\alpha-\mathrm{T}+\alpha-\mathrm{T}-3)+0.4(\beta-\mathrm{T}$ $+\beta-T-3)+0.2(\gamma-T+\gamma-T-3)+0.02(\delta-T+\delta-T-3)$ to convert milligrams of tocopherols into International Units of Vitamin $\mathrm{E}$. They suggeted that the ratio of vitamin E (I.U.): polyunsaturated fatty acids (g) should be $I \cdot O$ for man and $2-2 \cdot 5$ 
Table 2. Tocopherols (mg/100 g) in whole cereal grains (Morrison, 1977)

$\begin{array}{lcccccccc}\quad \text { Cereal } & \alpha-T & a-T-3 & \beta-T & \beta-T-3 & \gamma-T & \gamma-T-3 & \delta-T & \delta-T-3 \\ \text { Barley } & 0.2-0.97 & 1 \cdot I-4.0 & 0.04-0.4 & 0.3-0.7 & 0.03-0.5 & 0.2 & 0.01-0.04 & 0.16 \\ \text { Maize } & 0.6-2 \cdot 1 & 0.2-0.5 & & & 2.9-5.0 & 0.5-1 \cdot 1 & & \\ \text { Millet } & 0.05 & & \text { trace } & & 1.3 & & 0.4 & \\ \text { Oats } & 0.3-1 \cdot 7 & 0.7-1 \cdot 1 & 0.1-0.2 & 0.1-0.3 & 0.3 & & & \\ \text { Rice } & 0.35 & & & & 0.035 & & \\ \text { Rye } & 0.5-1.8 & 0.7-1.5 & 0.3-0.7 & 0.8-0.9 & 0.6 & & & \\ \text { Triticale } & 0.7-1.45 & & & & & & & \\ \text { Wheat } & 0.9-1.8 & 0.3-0.7 & 2.5-3.6 & 2.5-3.6 & & & \end{array}$

Table 3. Distribution of tocopherols $(\mathrm{mg} / \mathrm{100} \mathrm{g})$ in maize and wheat (Morrison, 1977)

\begin{tabular}{|c|c|c|c|c|c|c|c|}
\hline Maize & $\alpha-T$ & $a-T-3$ & $\beta-\mathrm{T}$ & $\beta-T-3$ & $\gamma-\mathrm{T}$ & $\gamma-\mathrm{T}-3$ & Total \\
\hline $\begin{array}{l}\text { sected } \\
\text { ndosperm } \\
\text { sected pericarp } \\
\text { sected germ } \\
\text { rm oil (high }\end{array}$ & $\begin{array}{l}0.05-0.07 \\
0.5-0.75 \\
12.9-19.4\end{array}$ & $\underset{\text { trace }}{4 \cdot 5-8 \cdot 7}$ & & & $\begin{array}{c}1 \cdot 0-1 \cdot 9 \\
1 \cdot 7-2 \cdot 0 \\
33 \cdot 2-38 \cdot 8\end{array}$ & $\begin{array}{c}3.8-18 \cdot 9 \\
\text { trace }\end{array}$ & $\begin{array}{c}11 \cdot 2-30 \cdot 2 \\
2 \cdot 55-3 \cdot 2 \\
47-58 \cdot 9\end{array}$ \\
\hline $\begin{array}{l}\text { alues) } \\
\text { rm oil (low } \\
\text { alues) }\end{array}$ & $\begin{array}{l}27-32 \\
13-23\end{array}$ & $\begin{array}{l}10-16 \\
2-10\end{array}$ & & & $\begin{array}{l}89-95 \\
4^{1-94}\end{array}$ & $21-27$ & $\begin{array}{l}149-168 \\
80-105\end{array}$ \\
\hline & & & & & & & \\
\hline $\begin{array}{l}\text { e flour } \\
\text { lipid } \\
\text { oil }\end{array}$ & $\begin{array}{c}0.26-0.34 \\
1.6-3 \cdot 3 \\
110-180 \\
133-149\end{array}$ & $\begin{array}{c}0.14 \\
I \cdot I \\
2.6-8.8\end{array}$ & $\begin{array}{c}0 \cdot 20-0 \cdot 22 \\
1 \cdot 0-1 \cdot 3 \\
66-81 \\
40-90\end{array}$ & $\begin{array}{c}1 \cdot 04-2 \cdot 18 \\
2 \cdot 9-5 \cdot 4 \\
9-18 \\
48-61\end{array}$ & $10-20$ & & $\begin{array}{l}1 \cdot 5-2 \cdot 8 \\
190-264 \\
268-305\end{array}$ \\
\hline
\end{tabular}

for pigs and poultry; by their criteria high-oil maize (ratio, 1 -28) and low-oil maize (ratio, 0.95 ) are just adequate for man and are deficient in vitamin $\mathrm{E}$ for pigs and poultry.

The composition and distribution of lipids in wheat, barley, rye and triticale are generally similar. Triglyceride-rich lipid is concentrated in the aleurone, scutellum and embryonic axis, and (in wheat) most of the glycolipids and phospholipids are in the endosperm.

Lipids, other than those inside the starch granules, tend to associate with protein in any fractionating process. Thus washed wheat gluten ( $4.9-6.6 \%$ lipid), protein concentrates obtained by dry milling (3.3-6.8\% lipid), and wet-alkaline process protein concentrates $(7.9-24.5 \%$ lipid) are comparatively rich sources of lipids (Betschart, Saunders, Mon \& Kohler, 1975; Fellers, Shepherd, Bellard, Mossman, Johnston \& Wasserman, 1968; Wootton, 1966; Wu \& Sexson, 1975; Youngs, Medcalf \& Gilles, 1970). Oxidation of these lipids causes off-flavours, and limits the storage stability of the products unless measures are taken to inactivate lipoxygenase (Wallace \& Wheeler, 1972) and prevent autoxidation (Betschart et al. 1975). 
Oats are unique among the cereals because most of their lipid is located in the endosperm. The lipids in all kernel fractions are mostly triglyceride (Morrison, 1977). Groat oil content ranges from 2.0 to $11.6 \%$, with most samples in the range 5-9\% (Brown \& Craddock, I 972). The energy value of oats could be improved by breeding for high oil content, and it should also be possible to maintain high levels of $18: 2$ and reduce lipase activity (Forsberg, Youngs \& Shands, 1974; Frey \& Hammond, 1975; Youngs \& Püskülcü, 1976).

Most of the lipid in normal and high-oil maize varieties is concentrated in the germ, but there are significant quantities in the other parts of the kernel (Table 4). Experiments at the University of Illinois in continuous selection over seventy plant generations have produced an Illinois Low Oil strain with $0.4 \%$ oil, and an Illinois High Oil strain with $17 \%$ oil (Weber \& Alexander, 1975), but the yield per acre and the 18:2 content of the Illinois High Oil strain are not satisfactory.

Table 4. Proximate analysis of lipids in wheat flour and maize kernel fractions, with factors to interconvert weights of fatty acid methyl esters (FAME), fatty acids (FA) and lipids

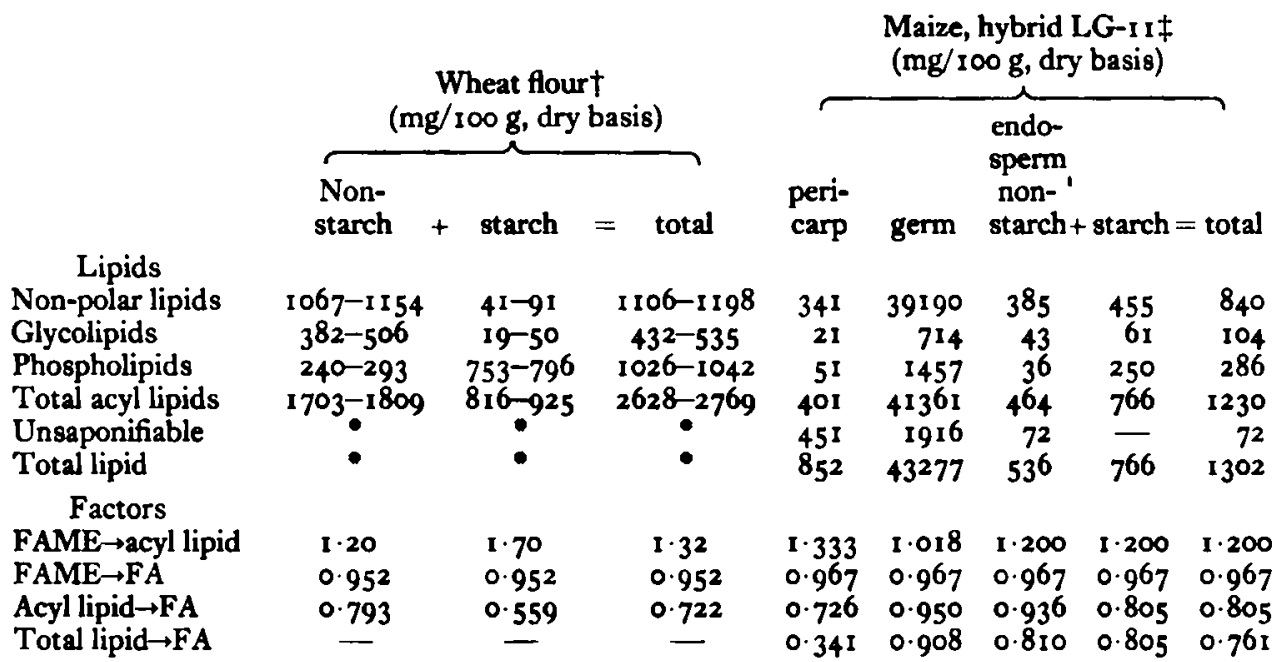

- No data available.

†Morrison et al. (1975).

¥S. L. Tan \& W. R. Morrison (unpublished results).

However, by means of alternative methods of selection, it is now possible to produce high-yielding hybrids $(\mathbf{7}-\mathbf{8 \%}$ oil) which compare favourably with commercial hybrids, the linoleate content of the oil can be controlled within wide limits, and it is even possible to have some control over the stereospecific distribution of fatty acids within the triglycerides (Weber \& Alexander, 1975). The heritability of $\beta$-carotene can also be controlled (Cabulea, 1971; Grogan \& Blessin, r968). 


\section{Quantitative analysis}

Quantitative methods of lipid analysis must be chosen to suit the tissue being analysed, and to give the required type of results: e.g., metabolizable energy value or essential fatty acid content. Methods based on weighing solvent-extracted material are in common use, but are open to criticism on several points: (i) nonpolar solvents, such as light petroleum and diethyl ether, are poor solvents for extracting polar lipids; (ii) polar mixtures, such as chloroform-methanol-water, extract a lot of non-lipid material; (iii) starch lipids are not extracted with any of the usual solvent systems; (iv) metabolizable energy value cannot be calculated from the weight of pure lipid without making an allowance for lipid components, such as unsaponifiable matter, which have little or no energy value; (v) the weight of lipid gives no information about essential fatty acid content.

One approach to these problems is to add a fatty acid internal standard ( $17: 0$ ) to lipids obtained by exhaustive extraction with an alcoholic solvent mixture, convert the fatty acid moieties into methyl esters (FAME), and quantify them by gas chromatography. In this way information on total fatty acid and essential fatty acid contents is obtained, and other (unsaponifiable) lipids are eliminated. However, this is an indirect approach, and with starchy material the results will be low unless solvents such as butanol-water at $90^{\circ}-100^{\circ}$ are used to extract the starch lipids (Acker \& Becker, 1971; Morrison, Mann, Wong \& Coventry, 1975).

Weihrauch, Kinsella \& Watt (1976) have collated results on the fatty acid contents of cereals and cereal products, and give factors to convert lipid weight into weight of total fatty acids. If metabolizable energy value is calculated from the weight of fatty acids, instead of from the weight of lipid, the results will in some cases be signficantly lower but more realistic. This is because the calculation does not include unsaponifiable matter such as $\beta$-sitosterol which will be largely unabsorbed, sugars in glycolipids which have a lower energy value than an equal weight of fatty acids, and phosphate esters in phospholipids which have little or no energy value.

An alternative approach is to add an internal standard (17:0) to the original sample, and then use acid hydrolysis to liberate all bound lipids, including those inside starch granules. The hydrolysate lipid and internal standard are then extracted, converted to FAME and quantified by gas chromatography (Morrison et al. 1975). Small corrections should be applied for unavoidable losses of unsaturated fatty acids. When the quantitative compositions of the lipid classes are known it is possible to calculate factors to convert FAME into total acyl lipids (i.e., lipids containing fatty acids), or to calculate fatty acid contents from total acyl lipids. Some examples are summarized in Table 4.

The lipid contents of wheat flour and starch shown in Table 4 are much higher than usually reported (Mecham, I971; Weihrauch et al. 1976), mainly because the acid hydrolysis-methanolysis-gas chromatography method gives complete quantification of the starch lipids. It is quite likely that if other starchy cereal products were analysed by this method, accepted figures for lipid and essential fatty acid contents (Weihrauch et al. 1976) would be found to be too low. 
Other discrepancies may come to light when improved analytical methods are applied to other cereal tissues.

\section{REFERENCES}

Acker, L. \& Becker, G. (1971). Stärke 23, 419.

Bauernfeind, J. C. (1972). F. Agric. Fd Chem. 20, 456.

Beringer, H. \& Dompert, W. U. (1976). Fette Seifen AnstrMittel. 78, 228.

Betschart, A. A., Saunders, R. M., Mon, T. R. \& Kohler, G. O. (1975). Cereal Chem. 52, 439.

Bieri, J. G. \& Evarts, R. P. (1975). F. Am. diet. Ass. 66, 134.

Brown, C. M. \& Craddock, J. C. (1972). Crop Sci. 12, 514.

Cabulea, I. (1971). Proc. 5th Meet. Maire Sorghum Sect. Eur. Ass. Res. Plant Breed. 5, 85.

De la Roche, I. A., Alexander, D. E. \& Weber, E. J. (1971). Crop Sci. I1, 856.

De la Roche, I. A., Andrews, C. J., Pomeroy, M. K., Weinberger, P. \& Kates, M. (I972). Can. $\mathcal{F}$. Bot. 50, 240 I.

De la Roche, I. A., Pomeroy, M. K. \& Andrews, C. J. (1975). Cryobiology 12, 506.

De Silva, N. S., Weinberger, P., Kates, M. \& de la Roche, I. A. (1975). Can. F. Bot. 53 , I899.

Farkas, T., Déri-Hadlacsky, E. \&. Adonisz, B. (1975). Lipids 10, 331.

Fellers, D. A., Shepherd, A. D., Bellard, N. J., Mossman, A. P., Johnston, P. H. \& Wasserman, T. (1968). Cereal Chem. 45, 520.

Flora, L. J. \& Wiley, R. C. (1972). F. Am. Soc. hort. Sci. 97, 604.

Forsberg, R. A., Youngs, V. L. \& Shands, H, L. (1974). Crop Sci. I4, 221.

Frey, K. J. \& Hammond, E. G. (1975). F. Am. Oil Chem. Soc. 52, $35^{8}$.

Grogan, C. O. \& Blessin, C. W. (1968). Crop Sci. 8, 730.

Jellum, M. D. (1970). f. Agric. Fd Chem. 18, 365.

Mecham, D. K. (1971). In Wheat, Chemistry and Technology, p. 393, [Y. Pomeranz, editor]. A.A.C.C. monogr. ser., vol. III., and edn. St. Paul, Minn.: American Association of Cereal Chemistry.

Mihajlović, M., Hadži-Tasković, V., Sukalović, V. \& Marković, G. (1971). Proc. 5th Meet. Maize Sorghum Sect. Eur. Ass. Res. Plant Breed. 5, 82.

Morrison, W. R. (1977). Ado. Cereal Sci. Technol. 2, (In the press).

Morrison, W. R., Mann, D. L., Wong, S. \& Coventry, A. M. (1975). F. Sci. Fd Agric. $26,507$.

Nechaev, A. P. \& Sandler, Zh. Ya. (1975). Grain Lipids, I59 pp. Moscow: Kolos.

Poneleit, C. G. \& Baumann. L. F. (1970). Crop Sci. ro, $33^{8}$.

Quackenbush, F. W., Firch, J. G., Brunson, A. M. \& House, L. R. (1963). Cereal Chem. 40, 250.

Redshaw, E. S. \& Zalik, S. (1968). Can. 7. Biochem. 46, rog3.

Siklósi-Rajki. E. \& Faragó, L. (1974). Acta aliment. Acad. Sci. Hung. 3, 389 .

Slover, H. T. (1971). Lipids 6, 291.

Thompson, D. L., Jellum, M. D. \& Young, C. T. (1973). F. Am. Oil Chem. Soc. 50, 540.

Wallace, J. M. \& Wheeler, E. L. (1972). Cereal Chem. 49, 92.

Weber, E. J. (1973). In Industrial Uses of Cereals, p. I6I, [Y. Pomeranz, editor]. St. Paul, Minn.: American Association of Cereal Chemistry.

Weber, E. J. \& Alexander, D. E. (1975). F. Am. Oil Chem. Soc. 52, 370.

Weihrauch, J. L., Kinsella, J. E. \& Watt, B. K. (1976). F. Am. diet. Ass. 68, 335.

Wootton, M. (1966). F. Sci. Fd Agric. 17, 297.

Wu, Y. V. \& Sexson, K. R. (1975). F. Agric. Fd Chem. 23, 906.

Youngs, V. L., Medcalf, D. G. \& Gilles, K. A. (1970). Cereal Chem. 47, 640.

Youngs, V. L. \& Püskülcü, H. (1976). Crop Sci. 16, 881. 